Louisiana State University

LSU Digital Commons

Faculty Publications

Department of Biological Sciences

$1-1-1987$

\title{
Structure and expression of the Saccharomyces cerevisiae CRY1 gene: A highly conserved ribosomal protein gene
}

J. C. Larkin

Carnegie Mellon University

J. R. Thompson

Carnegie Mellon University

J. L. Woolford

Carnegie Mellon University

Follow this and additional works at: https://digitalcommons.Isu.edu/biosci_pubs

\section{Recommended Citation}

Larkin, J., Thompson, J., \& Woolford, J. (1987). Structure and expression of the Saccharomyces cerevisiae CRY1 gene: A highly conserved ribosomal protein gene. Molecular and Cellular Biology, 7 (5), 1764-1775. https://doi.org/10.1128/MCB.7.5.1764

This Article is brought to you for free and open access by the Department of Biological Sciences at LSU Digital Commons. It has been accepted for inclusion in Faculty Publications by an authorized administrator of LSU Digital Commons. For more information, please contact ir@lsu.edu. 


\title{
Structure and Expression of the Saccharomyces cerevisiae CRY1 Gene: a Highly Conserved Ribosomal Protein Gene
}

\author{
JOHN C. LARKIN,† J. RYAN THOMPSON, AND JOHN L. WOOLFORD, JR.* \\ Department of Biological Sciences, Carnegie Mellon University, Pittsburgh, Pennsylvania 15213
}

Received 15 July 1986/Accepted 12 February 1987

\begin{abstract}
The Saccharomyces cerevisiae CRY1 gene encodes ribosomal protein rp59, a component of the 40S ribosomal subunit. Mutations in $C R Y 1$ can confer resistance to the alkaloid cryptopleurine, an inhibitor of the elongation step of translation. The nucleotide sequence of the cloned $C R Y 1$ gene was determined. The predicted amino acid sequence shows that $C R Y 1$ encodes a 14,561-dalton polypeptide that has $88 \%$ amino acid sequence homology to the hamster or human S14 ribosomal protein responsible for emetine resistance and $45 \%$ homology to Escherichia coli ribosomal protein S11. Analysis of the DNA sequences upstream from CRY1 revealed the presence of three sequences, HOMOL1 (consensus, A/TACATCC/TG/ATA/GCA), RPG (consensus, ACCCA/ GTACATT/CT/A), and a thymine-rich sequence, found upstream of more than 20 other cloned yeast genes encoding components of the translational apparatus. We exploited the ability to assay the expression of $C R Y 1$ in vivo by using the cryptopleurine resistance phenotype to demonstrate that these three consensus sequences are necessary for the transcription of $C R Y 1$. We previously showed that the upstream promoter element of the yeast RP39A gene consists of these identical sequence motifs. Therefore, we suggest that these three sequences define a consensus promoter element for the genes encoding the yeast translational apparatus. CRYI is one of several hundred yeast genes, including ribosomal protein genes, whose expression is transiently decreased 10-fold upon heat shock. We found that the HOMOL1 and RPG consensus sequences are not necessary for the heat shock response of $C R Y 1$.
\end{abstract}

The biosynthesis, assembly, and function of ribosomes are complicated interrelated processes essential to the function and growth of all cells. Equimolar quantities of more than 70 different ribosomal proteins synthesized in the cytoplasm and four ribosomal RNAs transcribed in the nucleus are assembled into ribosomes in the nucleolus (16). Ribosome biosynthesis is tightly coordinated with the physiological state of the cells. In the yeast Saccharomyces cerevisiae, the rate of synthesis of ribosomal proteins is coordinately decreased in response to heat shock (31) or upon sporulation (33) and is increased when the yeast is shifted from medium containing ethanol as a carbon source to medium containing glucose as a carbon source (29). To study the coordinate expression of ribosomal genes and the role of individual ribosomal components in yeast ribosome assembly and function, we and other workers have cloned a number of yeast ribosomal protein genes $(4,5,13-15,22,35,37,39,60$, 72). With few exceptions, these genes are unlinked, occur in two copies in the genome, and contain a single intervening sequence $(1,4,5,13-16,28,35,48,72,73)$.

Experiments thus far indicate that a variety of control mechanisms operate to coordinate yeast ribosome biosynthesis. Ribosomal protein mRNA transcription, processing, stability, and translation are regulated, as well as the stability of the ribosomal proteins themselves $(11,12,18,19$, $29-31,33,53,67,69,71)$. Several cloned ribosomal protein genes have been used as probes to demonstrate that yeast ribosomal protein mRNAs have similar rates of synthesis and turnover and accumulate in roughly equimolar quantities (30). Coordinate transcription of the unlinked ribosomal protein genes may result from activation of identical or very similar promoter sequences upstream of each of these genes.

\footnotetext{
* Corresponding author.

† Present address: Department of Genetics and Cell Biology, University of Minnesota, St. Paul, MN 55108.
}

We have recently identified by detailed mutational analysis three sequence motifs upstream of the RP39A gene necessary for its transcription (58). These sequences are present in the same $5^{\prime}$-to-3' orientation upstream of 18 of the 20 cloned ribosomal protein genes $(38,58,66)$, as well as the translational elongation factor genes TEFI and TEF2 (23).

To facilitate our studies of yeast ribosome biogenesis, we isolated a ribosomal protein gene with a readily assayable phenotype, sensitivity or resistance to the plant alkaloid cryptopleurine. Cryptopleurine inhibits protein synthesis in yeasts and other eucaryotes by binding to a high-affinity site on the $40 \mathrm{~S}$ subunit and blocking the elongation factor EF-2dependent translocation step $(2,6)$. Cryptopleurine resistance in yeasts is due to a recessive nuclear gene, cryl, which is closely linked to the mating type locus (MAT) on chromosome III $(20,62)$. The cryl resistance allele and the wild-type sensitivity allele $C R Y I$ have been cloned and have been shown to encode the $40 \mathrm{~S}$ subunit ribosomal protein rp59 $(22,35)$.

In this study, we analyzed the structure of the $C R Y I$ gene. The CRYl gene is transcribed into a 960 -nucleotide poly $(\mathrm{A})^{+}$ transcript containing a single 307-nucleotide intron interrupting the third codon, which is removed to produce a 630 nucleotide poly(A) ${ }^{+} C R Y I$ mRNA. A comparison of the predicted amino acid sequence of the $\mathrm{rp} 59$ protein encoded by $C R Y I$ with the sequence of the Chinese hampster ovary cell and human $\mathrm{S} 14$ ribosomal proteins $(54,55)$ reveals a striking $(88 \%)$ conservation of sequence between these yeast and mammalian proteins.

We constructed a series of $5^{\prime}$ deletion mutations that identified upstream sequences necessary for in vivo expression of the CRYI gene. This analysis revealed that $C R Y I$ utilizes the same consensus tripartite promoter sequences as the yeast $R P 39 A$ and $L 25$ ribosomal protein genes $(58,74)$, corroborating our model that transcription of yeast ribosomal protein genes is mediated by this consensus promoter. 
We also examined the effect of the 5 ' deletion mutations on CRYI transcription during heat shock. Our results show that deletion of the HOMOL1 and RPG consensus sequences does not interfere with the transient decrease in transcription occurring after heat shock. These results suggest that the sequences required for the coordinate heat shock response of ribosomal protein genes are separate from the ribosomal protein gene constitutive promoter element.

\section{MATERIALS AND METHODS}

Strains and media. Yeast strain JL8 ( $\alpha$ cryl leu2-3,112 ura3-52 trpl) was constructed by crossing strains BJ423 ( $\alpha$ cryl hisl; kindly provided by Elizabeth W. Jones) and DBY747 (a his3- $\Delta 1$ leu2-3,112 ura3-52 trp1-289; obtained from the Yeast Genetic Stock Center, Berkeley, Calif.). An $\alpha$ cryl leu2 trpl spore was crossed to strain RL78 (a ura3-52), which was constructed in our laboratory by Robert Last (36). Progeny from this cross were backcrossed to RL78 three more times before strain JL8 was chosen. Standard yeast genetic methods were used for these manipulations (49).

Yeast cells were grown either in YEPD (1\% yeast extract, $2 \%$ peptone, $2 \%$ dextrose) or in defined synthetic media supplemented with $2 \%$ dextrose as a carbon source (26). Cryptopleurine phenotypes were assayed on media containing 5 to $15 \mu \mathrm{M}$ cryptopleurine, which was obtained from Chemasea or Corkwood Enterprises, Unit F, 61 Waratah St., Kirrawee, New South Wales, Australia.

Materials. Restriction site linkers, restriction endonucleases, nuclease BAL 31, and calf alkaline phosphatase were obtained from New England BioLabs, Inc., or Boehringer Mannheim Biochemicals. T4 polynucleotide kinase was a gift from William McClure, Carnegie Mellon University. Escherichia coli DNA polymerase holoenzyme and Klenow fragment were gifts from William E. Brown, Carnegie Mellon University. T4 DNA ligase, $\left[\alpha-{ }^{32} \mathrm{P}\right] \mathrm{dCTP}$, and $\left[\gamma^{32}\right.$ P]ATP were obtained from New England Nuclear Corp. DEAE-nitrocellulose (NA 45) was obtained from Schleicher \& Schuell, Inc. The synthetic oligonucleotide 5' GTATCGTTGAAAGAAGCG 3' was purchased from DNA Synthesis Service, Department of Chemistry, University of Pennsylvania. Reverse transcriptase was obtained from Life Sciences, Inc. Plasmid pACTI containing the yeast actin gene was provided by Claudio Pikielny, Brandeis University.

Nucleic acid preparation. Bacterial plasmid DNA was prepared as described by Woolford and Rosbash (73). Restriction enzyme fragments were purified by agarose gel electrophoresis as described by Last et al. (36). CRYI cDNA clones were isolated from a yeast cDNA library constructed and kindly supplied by Gary McKnight (45). The ${ }^{32} \mathrm{P}$-labeled $E c o$ RI-BglII fragment from $C R Y I$ was used as a probe for colony hybridization (17) to approximately 20,000 colonies from the library. Plasmid DNAs were isolated from positive colonies and were screened by restriction enzyme mapping for those preparations containing CRYI cDNAs.

Yeast RNA was prepared as described previously $(21,35$, 36). Cultures $(200 \mathrm{ml})$ of each plasmid-bearing strain were grown in appropriate synthetic medium to a density of $2 \times$ $10^{7}$ to $4 \times 10^{7}$ cells per $\mathrm{ml} ; 100$-ml portions were harvested by centrifugation and were used to prepare RNA immediately. The remaining $100 \mathrm{ml}$ of each culture was pelleted, suspended in $5 \mathrm{ml}$ of $1 \mathrm{M}$ sorbitol, and stored frozen for use in the preparation of genomic DNA by the method of Davis et al. (9), with the modifications described by Last et al. (36). Plasmid copy numbers were determined from the same cultures used to determine $C R Y I$ RNA levels.

Gel electrophoresis, transfer, and filter hybridization of DNA and RNA. All restriction enzyme cleavages were performed as recommended by the manufacturer. DNA restriction fragments were subjected to electrophoresis as described by Woolford et al. (72). DNA was transferred to nitrocellulose by the method of Southern (63), with modifications described previously (35).

RNA [total RNA or poly(A) ${ }^{+}$RNA] was subjected to electrophoresis on $1.2 \%$ agarose gels and blotted onto nitrocellulose as described previously $(35,36)$. Both DNA and RNA blot filters were hybridized as described by Davis et al. (9) to DNA labeled in vitro with ${ }^{32} \mathrm{P}$ by nick translation (3, 56). Densitometry of autoradiograms was performed by using the tungsten lamp of a Zeineh soft laser scanning densitometer (model SL-504-XL). For each sample, either a series of dilutions or several exposures of the blot (generally both) were used to ensure that the density of each band quantitated was within the linear range of the film. To determine $C R Y 1$ mRNA levels in cells transformed with the CRYI deletion plasmids, the regions of the nitrocellulose filter corresponding to each band of interest were cut out, and the amount of radioactivity was determined by scintillation counting. These results were entirely in agreement with the RNA levels measured for these samples by using densitometry.

DNA ligations. Cohesive end ligation of DNA fragments was done as described previously (36). The attachment of synthetic DNA linkers to staggered-end or blunt-end restriction fragments was performed as described by Maniatis et al. (43).

Construction of $C R Y 1$ deletion plasmids. The details of the method used for construction of deletions upstream from the $C R Y l$ gene have been given elsewhere (Larkin, Ph.D. thesis, Carnegie Mellon University, Pittsburgh, Pa., 1985). Deletions were constructed starting from the HindIII site at position -454 upstream of the CRYI AUG initiation codon by using either BAL 31 digestion $(\Delta-273, \Delta-265, \Delta-257$, $\Delta-243, \Delta-200, \Delta-157, \Delta-152$, and $\Delta-123)$ or restriction sites occurring in the genomic sequence of this region $(\Delta-143$, $\Delta-114$, and $\Delta-46)$. BAL 31 digestions were done as described by Maniatis et al. (43). The resulting deletions were present on HindIII restriction fragments derived from the 2.2 kilobase (kb) genomic CRYI HindIII fragment, such that sequences were removed upstream from $C R Y I$ and a HindIII linker was placed at the deletion endpoint. Each of these deletion fragments was cloned into the HindIII site of YCp50 (a single-copy centromere plasmid) and YEp13 (a moderately high-copy-number $2 \mu \mathrm{m}$ circle plasmid) in such a manner that the HindIII linker at each deletion endpoint was joined to the same pBR322-derived sequences in each vector (Fig. 1). The structure of each deletion endpoint was confirmed by DNA sequencing of the YCp50 construction.

Yeast transformation. Yeast cells were transformed either by the spheroplast method described by Sherman et al. (61) or by the lithium acetate method described by Ito et al. (24). Transformants with integrating vectors were tested for stability as described by Last et al. (36).

DNA sequencing. DNA restriction fragments were 5 ' end labeled with $\left[\gamma-{ }^{32} \mathrm{P}\right] \mathrm{ATP}$ and T4 polynucleotide kinase as described by Maxam and Gilbert (44). Fragments were labeled at their $3^{\prime}$ ends by using $\alpha-{ }^{32} \mathrm{P}$-labeled deoxynucleoside triphosphates and the Klenow fragment of DNA polymerase, as described by Maniatis et al. (43). DNA sequenc- 

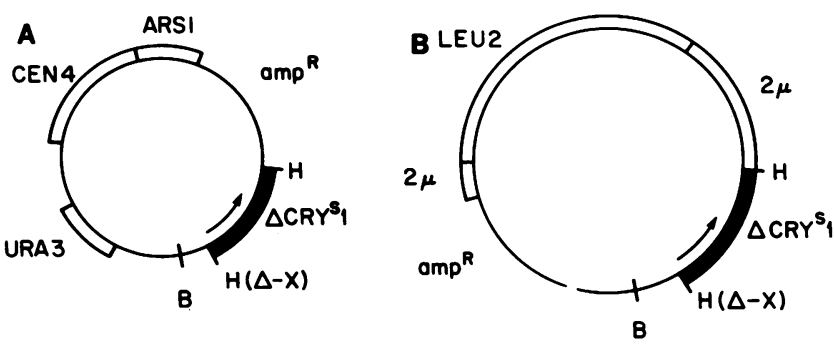

FIG. 1. Structure of yeast plasmids containing $C R Y 15^{\prime}$ deletions. (A) Single-copy centromere plasmid YCp50 CRYI $\Delta$-X. (B) Medium copy $2 \mu \mathrm{m}$ plasmid YEp13 $C R Y 1 \Delta-\mathrm{X}$. X refers to the position of the nucleotide at the deletion endpoint. Restriction endonuclease cleavage sites: H, HindIII; B, BamHI. Solid lines, pBR322 sequences; solid boxes, CRYI sequences; open boxes, yeast sequences other than $C R Y I$. The arrows indicate the location and direction of transcription of the CRYI gene.

ing reactions were performed as described by Maxam and Gilbert (44), except that the thymine-cytosine reaction was modified by increasing the amount of water to $100 \mu \mathrm{l}$, increasing the amount of hydrazine to $50 \mu \mathrm{l}$, and increasing the incubation time to $45 \mathrm{~min}$. This reaction has been found to give more efficient cutting at thymine residues than the standard reaction.

S1 mapping and primer extension analysis. The $3^{\prime}$ end of the $C R Y I$ intron and the $C R Y I$ transcript were determined by $\mathrm{S} 1$ mapping, using the protocol of Kaufer et al. (28) and double-stranded DNA fragments labeled at their 5' or '3' ends as described above. The DNA molecules were denatured and hybridized to mRNA for $5 \mathrm{~h}$ by continuously decreasing the temperature from 48 to $44^{\circ} \mathrm{C}$. Digestion was carried out with 100 or $200 \mathrm{U}$ of S1 nuclease (Sigma Chemical Co.) per $\mathrm{ml}$ at $37^{\circ} \mathrm{C}$. The sizes of RNA protected fragments were determined by electrophoresis alongside DNA size stan- dards and DNA sequence ladders on $8 \%$ polyacrylamide sequencing gels containing $8 \mathrm{M}$ urea.

The 5' ends of the CRYI mRNA were mapped by primer extension analysis by using the method of Treisman et al. (68) under the hybridization conditions described by Krainer et al. (34). A 5'-end-labeled oligonucleotide complementary to nucleotides +367 to +384 of $C R Y 1$ was annealed to $20 \mu \mathrm{g}$ of total RNA or poly $(\mathrm{A})^{+}$RNA. The reverse transcriptaseextended products were analyzed alongside DNA sequence ladders on an $8 \%$ polyacrylamide sequencing gel containing $8 \mathrm{M}$ urea.

\section{RESULTS}

Structure of the CRYI transcription unit. We previously showed that the yeast $C R Y 1$ gene encodes ribosomal protein rp59 and is present within a 2.2-kb HindIII fragment that is $21 \mathrm{~kb}$ centromere proximal from the MAT locus on chromosome III (35). Wild-type yeast cells contain a 630-nucleotide poly $(\mathrm{A})^{+}$transcript homologous to $C R Y 1$, whereas rna2 mutant yeast cells that are unable to splice introns accumulate a 960-nucleotide poly(A) ${ }^{+}$transcript homologous to $C R Y I$ (35). Therefore, we inferred that the CRYI gene contains one or more introns. The precise location and structure of the $C R Y 1$ gene and transcript were determined by sequencing DNAs from the cloned $C R Y I$ genomic fragment and a cloned full-length $C R Y I \mathrm{cDNA}$, as shown in Fig. 2 , and by $\mathrm{S} 1$ nuclease mapping and primer extension analysis (Fig. 3). The complete nucleotide sequence of $C R Y I$ and the 456 nucleotides upstream of the gene is shown in Fig. 4.

We directly demonstrated the presence of a single intron near the $5^{\prime}$ end of $C R Y I$ by comparing the structure and sequence of a $C R Y I \mathrm{cDNA}$ with the structure and sequence of the $C R Y 1$ genomic fragment. The $C R Y I$ cDNA sequence lacks nucleotides +8 to +314 , which are present in the genomic sequence within the third codon of the predicted $C R Y 1$ reading frame (Fig. 4). This interval within CRYI
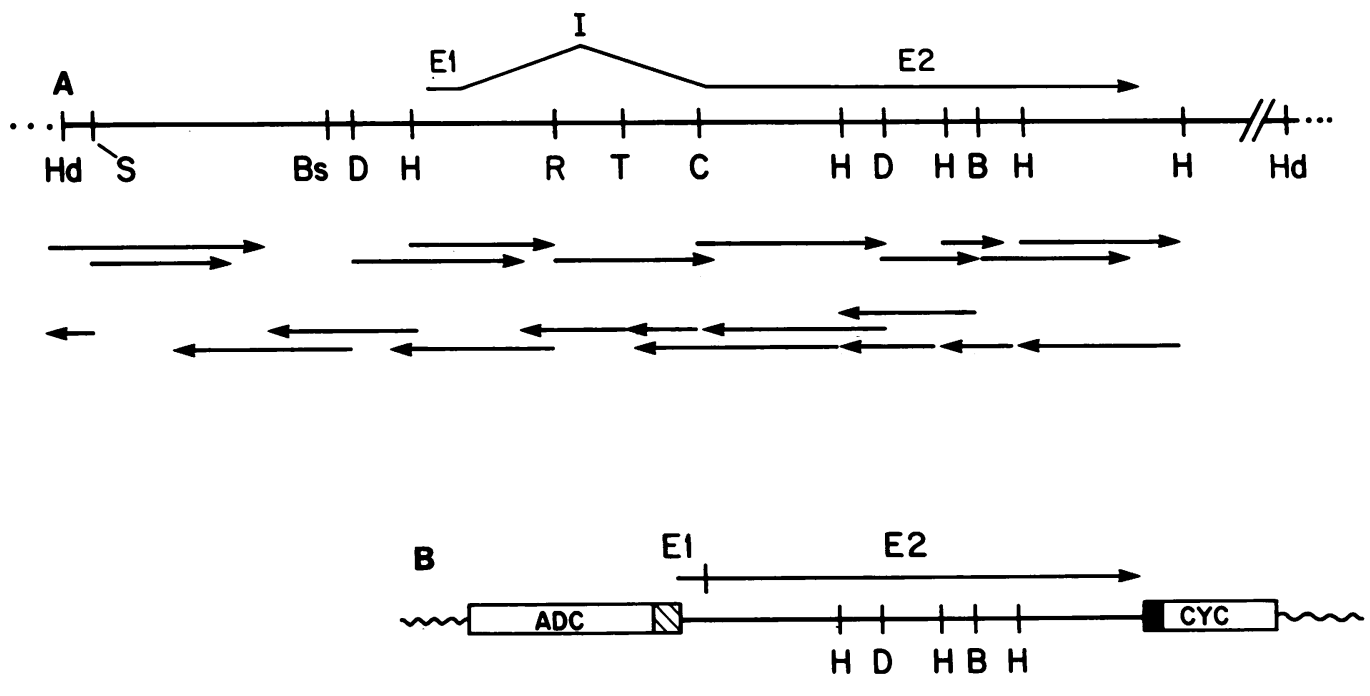

FIG. 2. Strategy for determining the DNA sequence of $C R Y 1$ genomic and CDNA clones. The maps of the $C R Y 1$ gene and of a $C R Y I$ cDNA clone show only those restriction enzyme sites used for DNA sequence analysis or comparison. The arrows indicate the direction and extent of nucleotide sequence read from the indicated 5 '-end-labeled $(\rightarrow)$ or $3^{\prime}$-end-labeled $(\leftarrow)$ sites. The $C R Y I$ transcripts are indicated by the arrows above each map; the CRYI intron (I) is represented by the "break" in the arrow, and the CRYI exons are designated E1 and E2. Restriction enzyme sites: Hd, HindIII; S, Sau96; Bs, Bst EII; D, DdeI; H, HinfI; R, EcoRI; T, TaqI; C, ClaI; B, BglII. (A) Structure and sequencing of the $C R Y 1$ genomic clone. (B) $C R Y I$ cDNA cloned in pMAC561. Open bars, Sequences containing the yeast $A D C$ promoter or the yeast $C Y C l$ transcriptional terminator; cross-hatched bar, G . C tailing; solid bar, A - T tailing; solid line, CRYI cDNA; wavy line, remaining vector sequences. 


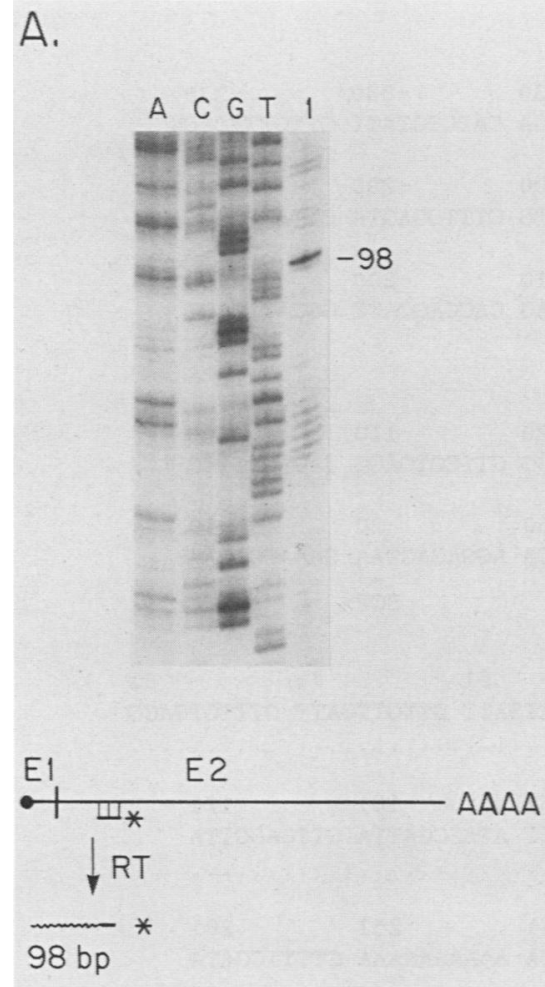

B.

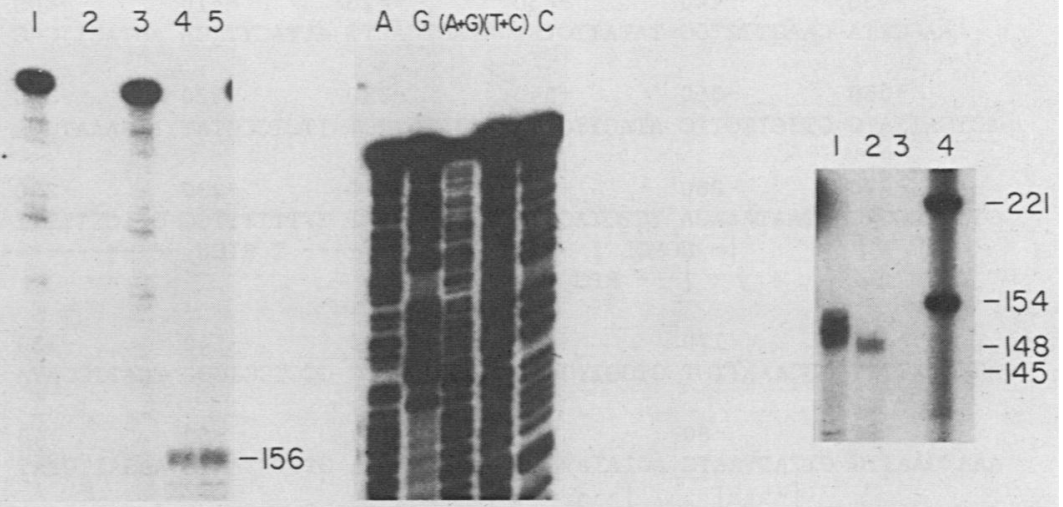

FIG. 3. Mapping the ends of the $C R Y I$ transcript and intron. (A) Primer extension analysis to map the 5 ' ends of the $C R Y I$ transcript. The 18-mer residue homologous to nucleotides 367 to 384 was $5^{\prime}$ end labeled and hybridized to poly $(A)^{+}$RNA from wild-type yeast cells, and cDNA was synthesized from the resulting hybrid by using avian myeloblastosis virus reverse transcriptase (RT). The radioactive DNA products were subjected to electrophoresis alongside a sequencing ladder on an $8 \%$ polyacrylamide $-8 \mathrm{M}$ urea sequencing gel as described in Materials and Methods. The 98-nucleotide product is shown in lane 1. No products were obtained when RNA, reverse transcriptase, or primer was omitted. (B and C) S1 nuclease mapping of the $3^{\prime}$ ends of the $C R Y I$ intron and the $C R Y I$ transcript. The 5'-end-labeled 340-nucleotide EcoRI-HinfI fragment and $3^{\prime}$-end-labeled 190 -nucleotide $H$ infl fragment were hybridized to poly $(\mathrm{A})^{+}$mRNA isolated from wild-type yeast cells, incubated with $100 \mathrm{U}$ of $\mathrm{S} 1$ nuclease for 15 or $30 \mathrm{~min}$ at $37^{\circ} \mathrm{C}$, and subjected to electrophoresis on $8 \%$ polyacrylamide- $8 \mathrm{M}$ urea gels alongside a sequencing ladder (B) or size standards (C). (B) Lanes 1 and 3, 340-nucleotide EcoRI-HinfI fragment without RNA or S1; lane 2, fragment without RNA plus S1; lane 4, fragment plus RNA plus S1 (15 min); lane 5, fragment plus RNA plus S1 (30 min). (C) Lane 1, 190-nucleotide Hinfl fragment plus RNA plus S1 (15 min); lane 2, fragment plus RNA plus S1 (30 min); lane 3, fragment minus RNA plus S1; lane 4, size standards. bp, Base pairs; R1, EcoRI site; Hf, HinfI site; S1, nuclease S1.

contains the following three sequence motifs found in all introns of yeast nuclear genes: GTATGT (nucleotides +8 to +13 ), which immediately follows $5^{\prime}$ splice sites; TACTAAC (nucleotides +260 to +266 ), which is present 9 to 57 nucleotides upstream of $3^{\prime}$ 'splice sites; and AG (nucleotides +313 to +314$)$, which immediately precedes $3^{\prime}$ splice sites. The $3^{\prime}$ splice site of the $C R Y 1$ intron was also mapped by using the S1 nuclease protection assay. The 340-nucleotide EcoRIHinfI fragment of $C R Y 1,5^{\prime}$ end labeled at the HinfI site, was hybridized to yeast mRNA and digested with S1. A 156nucleotide fragment was protected (Fig. 3B, lanes 4 and 5), indicating that the $3^{\prime}$ splice site of CRYI is between guanine and cytosine at positions 314 and 315 .

The 5' and 3' ends of the CRYI transcripts were mapped by primer extension and $\mathrm{S} 1$ analyses. A major cDNA product 98 nucleotides long was obtained (Fig. 3A, lane 1), indicating that at least one $C R Y I$ transcription 5' start site is at the adenine residue at position -21 (Fig. 4). Similar results were obtained by $\mathrm{S} 1$ protection analysis. One major and two minor start sites were detected (the adenine at position -21 , the cytosine at position -32 , and the thymine at position -38 , respectively) (data not shown). The $5^{\prime}$ end of the cloned $C R Y I$ cDNA was also found to be the adenine at position -21 . The $3^{\prime}$ termini of the $C R Y I$ transcripts were mapped by $\mathrm{S} 1$ digestion of hybrids between the 190- nucleotide 3 '-end-labeled CRYI HinfI fragment and yeast mRNA at various temperatures. Fragments 145 and 148 nucleotides long were protected (Fig. 3C, lane 2), indicating that the $C R Y 1$ transcript has $3^{\prime}$ termini at nucleotides +822 or $+825,123$ and 126 nucleotides downstream from the UGA termination codon at position 719 (Fig. 4). There is a poly(A) tract at the $3^{\prime}$ end of the CRYI cDNA sequence, following the cytosine at nucleotide 820 . However, since the genomic CRYI sequence contains adenine residues at positions 821 and 822 following the cytosine at nucleotide 820 , we could not unambiguously determine whether the $3^{\prime}$ end of the $C R Y I$ cDNA is $\mathrm{C}(+820), \mathrm{A}(+821)$, or $\mathrm{A}(+822)$.

Ribosomal protein rp59 encoded by $C R Y 1$ is homologous to bacterial and mammalian ribosomal proteins. Within the CRYI transcript defined above, there is one open reading frame of sufficient length to encode rp59 (Fig. 4). The hypothesis that this is in fact the $C R Y 1$ reading frame is supported by the fact that the dominant Crys phenotype is expressed in cryl yeast cells transformed with the CRYI cDNA cloned in yeast expression vector pMAC561.

The amino acid sequence of the $\mathrm{rp} 59$ protein predicted from the DNA sequence of $C R Y I$ consists of 137 amino acid residues comprising a basic protein with an approximate $\mathrm{pI}$ of 11.85 and a molecular weight of 14,561. As shown in Fig. 5 , the predicted amino acid sequence of yeast ribosomal 


\begin{tabular}{|c|c|c|c|c|c|c|c|c|}
\hline-450 & -440 & -430 & -420 & -410 & -400 & -390 & -380 & -370 \\
\hline AAGCTTA & CAAGTTCTGG & TATATTCTAT & ATACTCACTT & ATTACTTTCA & AGTACTTCAC & ACGGGCCTGA & CATCTCTATT & CTTGTTACTC \\
\hline-360 & -350 & -340 & -330 & -320 & -310 & -300 & -290 & -280 \\
\hline GATTATC & GTTCTTGTTC & ATACTTGTTA & TGTATCTTCT & TTCTCССТАT & TTAAAATGTA & ATAGAGACTG & ; CTTTGGAGTA & CITACGTGCG \\
\hline $\begin{array}{r}-270 \\
\text { GTACGGAC }\end{array}$ & $\begin{array}{r}-260 \\
\text { TTAATAAACA } \\
\mid- \text { HC }\end{array}$ & $\begin{array}{r}-250 \\
\text { TCTGTACATT } \\
\text { OMOL I - ||- }\end{array}$ & $\begin{array}{r}-240 \\
\text { TTACTACTCT } \\
-1\end{array}$ & $\begin{array}{r}-230 \\
\text { TTTTTTTTGC } \\
-- \text { T RICB }\end{array}$ & $\begin{array}{r}-220 \\
\text { GTTCTTTTTT }\end{array}$ & $\begin{array}{r}-210 \\
\text { TCACCTTCAG }\end{array}$ & CACGAGCATT & $\begin{array}{r}-190 \\
\text { GCCATTCTCT }\end{array}$ \\
\hline-180 & -170 & -160 & -150 & -140 & -130 & -120 & -110 & -100 \\
\hline
\end{tabular}

ACTGCATTTT GGCAAATGT CTGCTTGCG CAGACCATCC GCCTCCTGGC TCATTCCATA TGGTGCAGG CTTCCTCAGG TAGACAGTTG

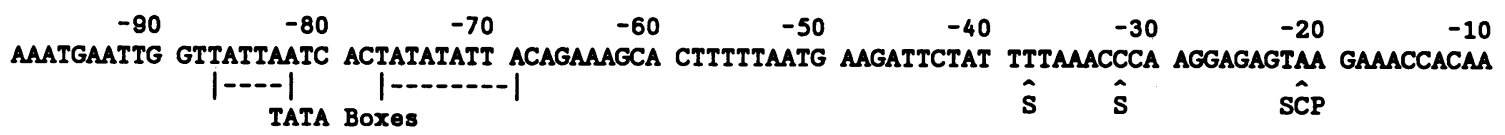

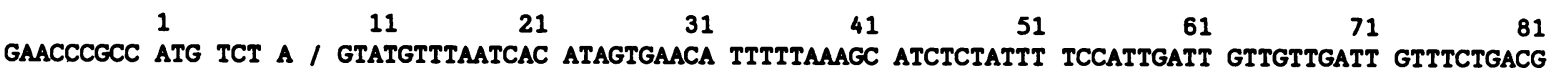

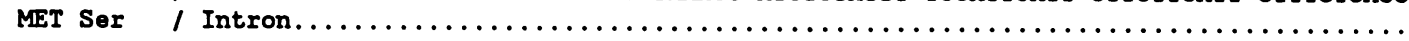

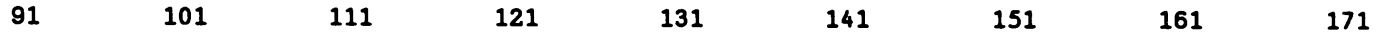
ACGTGCAAGA TACATTGAA GTCAGAACA TAAAGACAAT TCAACGAATT CATTGCCTCC AAAGTAATTC ATAGCGATTA GTTGAGCTTA

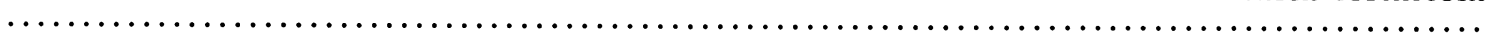

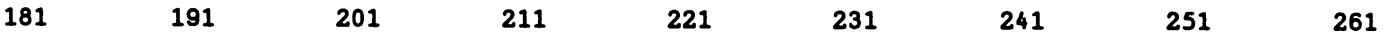

TTGTGTCAAT GGCAGTATAT TTTGTCAACT TTTTTTTCGA TGGAAAGCA AAGATACTAT GTAAGAATTA AAAAAMAM CTTTTGGATA

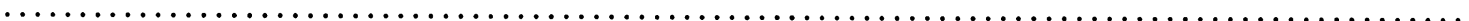

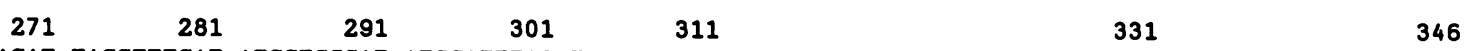

CTAACAACAT TACGTTTGAT ATCGTCCGAT ATCGATTTAC TATTTCCATT TAG / AC GTT GTT CAA GCT CGT GAC AAT TCC CAA GTT TIT $\ldots \ldots \ldots \ldots \ldots \ldots \ldots \ldots \ldots \ldots \ldots \ldots \ldots \ldots \ldots \ldots \ldots \ldots \ldots$ Intron /Asn Val Val Gln Ala Arg Asp Asn Ser Gln Val Phe

$\begin{array}{lllll}364 & 379 & 394 & 409 & 424\end{array}$

GGT GTT GCT AGA ATT TAC GCT TCT TTC AAC GAT ACT TTC GTT CAT GTT ACC GAT TTA TCT GGT AAG GAA ACC ATC Gly Val Ala Arg Ile Tyr Ala Ser Phe Asn Asp Thr Phe Val His Val Thr Asp Leu Ser Gly Lys Glu Thr Ile 1---- Primer Site -----1

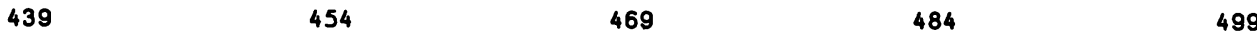

GCC AGA GTT ACT GGT GGT ATG AAG GTT AAG GCT GAC AGA GAT GAA TCT TCT CCA TAC GCT GCT ATG TTG GCT GCC Ala Arg Val Thr Gly Gly MET Lys Val Lys Ala Asp Arg Asp Glu Ser Ser Pro Tyr Ala Ala MET Leu Ala Ala

$514 \quad 529 \quad 544 \quad 559 \quad 574$ CAA GAT GTT GCC GCT AAG TGT AGG GAA GTC GGT ATC ACT GCC GTT CAC GTT AAG ATC AGA GCT ACC GGT GGT ACT Gln Asp Val Ala Ala Lys Cys Arg Glu Val Gly Ile Thr Ala Val Bis Val Lys Ile Arg Ala Thr Gly Gly Thr

$\begin{array}{lllll}589 & 604 & 619 & 634 & 649\end{array}$ AGA ACC AAG ACT CCA GGT CCA GGT GGT CAA GCT GCT TTG AGA GCT TTG GCC AGA TCT GGT TTG AGA ATT GGC CGT Arg Thr Lys Thr Pro Gly Pro Gly Gly Gin Ala Ala Leu Arg Ala Leu Ala Arg Ser Gly Leu Arg Ile Gly Arg

$664 \quad 679 \quad 694 \quad 709$

ATC GAA GAT GTT ACC CCA GTT CCA TGT GAC TCC ACC AGA AAG AAG GGT GGT AGA AGA GGT AGA AGA TTA TGA Ile Glu Asp Val Thr Pro Val Pro Cys Asp Ser Thr Arg Lys Lys Gly Gly Arg Arg Gly Arg Arg Leu ***

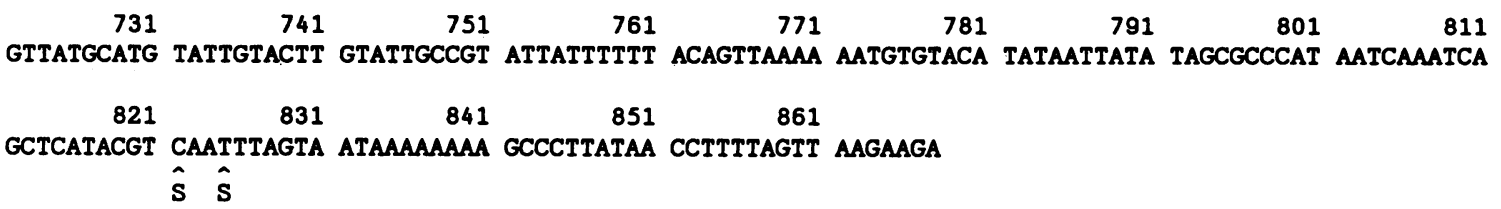

FIG. 4. DNA sequence of the $C R Y 1$ gene and predicted amino acid sequence of ribosomal protein rp59. The sequence of the mRNA identical strand of $C R Y l$ is shown. The open reading frame encoded by the $C R Y l$ transcript is translated into amino acids. The nucleotides are numbered with respect to the translation initiation codon, designated +1 . The vertical arrows in the $5^{\prime}$ and $3^{\prime}$ flanking regions mark the transcriptional initiation and termination sites, determined by S1 mapping (S), primer extension (P), and sequencing of the cDNA clone (C). The three consensus sequences (HOMOL1, RPG, and the thymine-rich region), the TATA boxes, and the sequence complementary to the oligonucleotide used for primer extension are underlined and labeled. This DNA sequence was previously published without any supporting data (66). 


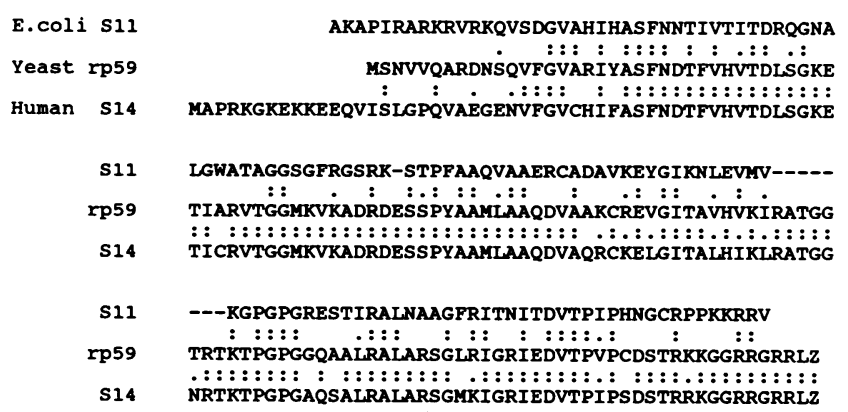

FIG. 5. Comparison of the primary structure of yeast $C R Y I$ ribosomal protein rp59, Chinese hamster cell $E m t B$ ribosomal protein S14, and E. coli ribosomal protein S11. Identical amino acid residues are indicated by two dots, and conservative amino acid substitutions are indicated by one dot.

protein $\mathrm{rp59}$ is extremely homologous to the sequence of human or hamster ribosomal protein $\mathrm{S} 14(54,55)$ and significantly homologous to the sequence of $E$. coli ribosomal protein $S 11$ (27). When the alignment shown in Fig. 5 was used, 109 of 137 residues of rp59 $(80 \%)$ were identical to residues in the $\mathrm{S} 14$ protein, and another 11 residues were conservative substitutions, such that there was an overall level of homology of $88 \%$. The sequence of rp59 is $45 \%$ homologous to that of S11; 47 of $137(37 \%)$ of the rp59 residues are identical to residues in S11, and 11 more are conserved substitutions. The mammalian proteins contain an additional 14 amino acids at their amino termini that are not present in rp59.

CRY1 upstream promoter element. The 5' DNA sequences necessary for expression of $C R Y I$ were determined by analyzing the expression of deletion mutations of $C R Y 1$ transformed into cryl yeast cells. Deletions of the $5^{\prime}$ end of the wild-type $C R Y I$ allele were constructed starting from the HindIII site at position -454 by using exonuclease BAL 31 . Because this HindIII site lies within a small nuclear RNA gene upstream from CRYI (Thompson et al., manuscript in preparation), we expected that all sequences required for proper CRYI expression would be downstream of this site. The wild-type HindIII fragment and the HindIII fragments carrying each deletion were cloned into both single-copy centromere vector $\mathrm{YCp} 50$ and multicopy $2 \mu \mathrm{m}$ vector $\mathrm{YEp} 13$ (Fig. 1). All deletions were named by the position of the first remaining nucleotide upstream of $C R Y 1$, numbered relative to the position of the $C R Y I$ translation initiation codon (Fig. 4 and 6).

Each single-copy YCp50 plasmid construction was transformed into cryl strain JL8, and the cryptopleurine resistance phenotype was assayed. Cryptopleurine resistance is fully recessive in heterozygous $C R Y I / c r y l$ diploids at the drug concentrations used in this study. As expected, the 2.2-kb HindIII fragment containing wild-type CRYI transformed JL8 to cryptopleurine sensitivity when it was cloned into $\mathrm{YCp} 50$, indicating that a single functional copy of the $C R Y 1$ allele is sufficient to transform this haploid $\mathrm{Cry}^{\mathrm{T}}$ strain to $\mathrm{Cry}^{\mathrm{s}}$. Three phenotypic classes could be distinguished among the JL8 transformants containing CRY1 deletion plasmids on the basis of their cryptopleurine resistance in JL8 (Fig. 6 and 7). Deletion mutations $\Delta-273$ and $\Delta-265$ transformed JL8 to the same level of cryptopleurine sensitivity as did the plasmid containing the wild-type $C R Y I$ gene on the 2.2-kb HindIII fragment. YCp50 $\Delta-257$ transformants showed increased cryptopleurine resistance, indicating that expression of this plasmid-borne $C R Y I$ deletion mutation was reduced in these transformants. Deletions up to and including YCp50 $\Delta-114$ resulted in this same intermediate $\mathrm{Cry}^{\mathrm{r}}$ phenotype. The YCp50 $\Delta-46$ deletion resulted in transformants as fully resistant to cryptopleurine as $\mathrm{YCp} 50$ vector transformants.

The cryptopleurine resistance phenotype was also determined for cryl yeast cells transformed with each deletion cloned in moderately high-copy-number vector YEp13. All of the deletions conferred full cryptopleurine sensitivity, with the exception of YEp13 $\Delta-46$ transformants, which were as resistant to cryptopleurine as YEp13 vector transformants. To obtain a more quantitative measurement of the effects of these deletions on $C R Y 1$ expression, we measured the amount of rp59 mRNA present in these transformants containing the deletion series in YEp13. Under these conditions the majority of rp59 mRNA within the cells was transcribed from the plasmid-borne $C R Y 1$ gene. Identical amounts of rp59 mRNA were detected in cells transformed with wild-type YEp13 CRY1 (YEp13 $\Delta$-454) or deletion mutant YEp13 $\Delta-273$ or YEp13 $\Delta-265$ (Fig. 8, lanes 2 through 4). A 60 to $70 \%$ decrease in rp 59 mRNA levels was observed between the YEp13 $\Delta-265$ deletion and the YEp13 $\Delta-257$ deletion (Fig. 8, lanes 4 and 5). A further three- to four-fold decrease in rp59 mRNA levels was observed between the YEp13 $\Delta$-243 deletion and the YEp13 $\Delta-200, \Delta-158, \Delta-152$, $\Delta-143$, and $\Delta-123$ deletions (Fig. 8, lanes 6 through 11). The YEp13 $\Delta-46$ deletion resulted in at least an additional twofold decrease in rp59 mRNA compared with the YEp13 $\Delta-114$ deletion (data not shown), which is consistent with its decreased phenotypic expression either YCp50 or YEp13. Primer extension analysis of RNAs from wild-type and mutant transformants yielded identical quantitative results and also demonstrated that transcripts with identical $5^{\prime}$ ends were produced by each $C R Y I$ construction (data not shown).

To examine the possibility that variations in plasmid copy number could have been responsible for the observed changes in mRNA levels, DNAs were isolated from the same cultures used to prepare RNA. Southern blot analysis of these DNAs, quantitated by densitometry of autoradiograms and by scintillation counting of the bands excised from the filters, revealed no detectable change in plasmid copy number (data not shown).

In all of the deletions resulting in decreased CRYI mRNA levels, starting with YEp13 $\Delta-257$, three minor transcripts (X, Y, and Z) appeared (Fig. 8, lanes 5 through 11). These transcripts decreased in size with increasing deletion size, suggesting that they spanned the deletion endpoint. These transcripts hybridized to $\mathrm{pBR} 322$-derived vector sequences $5^{\prime}$ to the CRYI gene and also to the 2.2-kb CRYI HindIII fragment, suggesting that they may be transcripts originating from readthrough from cryptic promoter sequences in the pBR322 DNA. A similar aberrant transcript was observed when the $R P 39 A$ promoter was inactivated (58).

CRYI upstream promoter element is not required for the heat shock effect. The most clearly defined example of regulation of transcription of yeast ribosomal protein genes is the abrupt but transient decrease in transcription of most of these genes when yeast cells are subjected to a heat shock (31). To determine which, if any, sequences $5^{\prime}$ to $C R Y 1$ are involved in mediating this heat shock response, we assayed the amount of rp59 mRNA present in cells containing wild-type $C R Y I$ or one of the $C R Y I 5^{\prime}$ deletion constructions cloned in YEp13 $(\Delta-257, \Delta-243, \Delta-200$, and $\Delta-114)$ at various times after the cells were shifted from 23 to $36^{\circ} \mathrm{C}$ (Fig. 9). We expected that the effect of heat shock on the CRYI transcript 


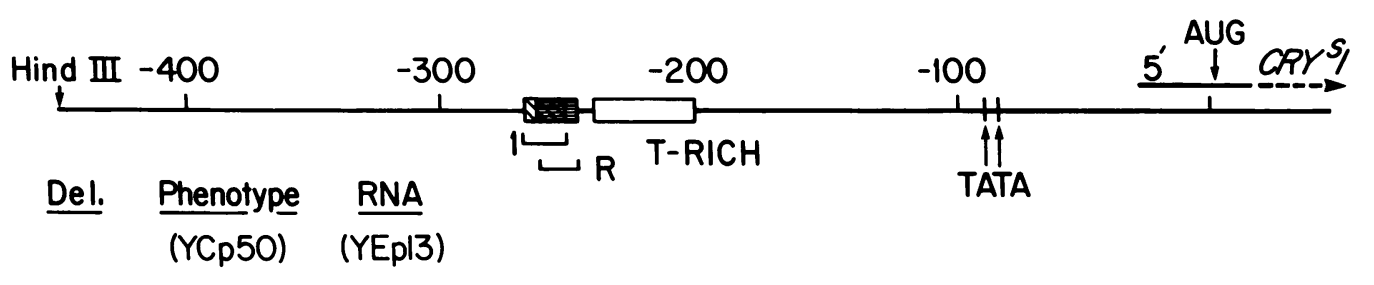

$\begin{array}{lcl}\Delta-454 & + & 1.00 \\ \Delta-273 & + & 1.00 \\ \Delta-265 & + & 1.00 \\ \Delta-257 & -1+ & 0.35 \\ \Delta-243 & -/+ & 0.40 \\ \Delta-200 & -/+ & 0.10 \\ \Delta-158 & -/+ & 0.10 \\ \Delta-152 & -/+ & 0.10 \\ \Delta-143 & -/+ & 0.10 \\ \Delta-123 & -/+ & 0.10 \\ \Delta-114 & -/+ & 0.10 \\ \Delta-46 & - & <0.05 \\ \text { Vector } & - & 0.03\end{array}$

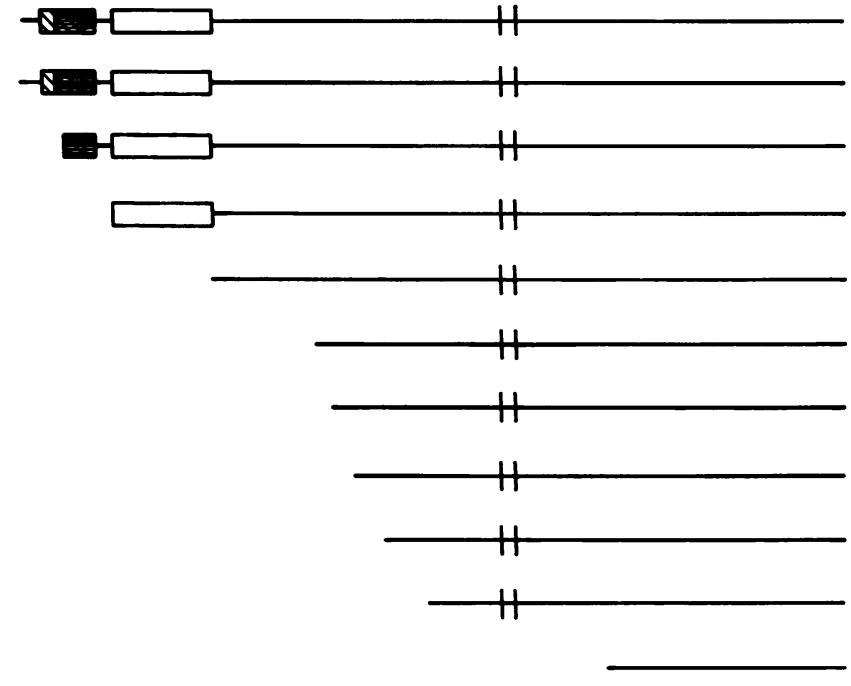

FIG. 6. Structure and expression of $C R Y I 5^{\prime}$ deletion mutations. The expression of each $C R Y I$ mutation in vivo was measured by assaying the cryptopleurine resistance of YCp50 CRYI $\Delta$ transformants of cryl strain JL8 and the amount of rp59 mRNA homologous to CRY1 in YEp13 CRYI $\Delta$ transformants of JL8. The Cry phenotypes are summarized from the results shown in Fig. 7 and are distinguished into the following three classes: $(+)$, completely functional $C R Y 1$ gene conferring full Crys phenotype; $(+/-)$, partially functional $C R Y I$ gene yielding partially Cry transformants; (-), nonfunctional $C R Y l$ gene yielding fully Cry transformants. The amount of rp59 mRNA in each transformant was determined by densitometric analysis of multiple exposures of blots of dilutions of each RNA sample over a 10-fold range. This procedure ensured that the density of each band quantitated was within the linear range of the film. All values were normalized both to the level of nonribosomal protein transcript 11-10 (see Fig. 8) and to the signal from the YEp13 CRYI transformed strain. Second, the bands were cut from the filters and counted by liquid scintillation. Identical results were obtained by both methods. The HOMOL1 (aw), RPG (巨), thymine-rich ( $\square$ ), TATA (+) consensus sequences are indicated. The CRYI transcript is indicated by an arrow, and the CRYI translational initiation codon is indicated by AUG.

from each plasmid-borne gene would be readily detectable over the background of chromosomal cryl transcripts and that the copy number of the plasmids would not be altered during the 1-h heat shock, since this is significantly less than one cell doubling time. It is clear from Fig. 9 that the levels of $C R Y 1$ mRNA expressed from the $\Delta-257$ and $\Delta-243$ deletions were still subject to the heat shock effect. The levels of CRY1 transcripts decreased markedly 20 to 40 min after heat shock, compared with the nonribosomal protein transcripts from the 11-10 and $A C T 1$ genes, and returned to normal levels by $60 \mathrm{~min}$. The $\Delta-200$ and $\Delta-114$ deletion mutants also showed a dramatic reduction in $C R Y I \mathrm{mRNA}$ levels after heat shock. However, these results are difficult to interpret, since the relative contribution of $\mathrm{rp} 59 \mathrm{mRNA}$ from the chromosomal cryl gene was greater in these two mutants. These results demonstrate that no sequence 5 ' of nucleotide -243 , including the HOMOL1 and RPG upstream promoter elements located between nucleotides -263 and -249 , is necessary for the response of the CRYI gene to heat shock.

\section{DISCUSSION}

CRYI gene. The primary transcript of the CRYI gene is 847 nucleotides long and contains a single 307-nucleotide intron within the third codon of the open reading frame encoding rp59. The sequences at the $5^{\prime}$ and $3^{\prime}$ ends of the CRYI intron conform to the consensus sequences present at all yeast splice junctions (66). The sequence TACTAAC, present within the CRYI intron, has been found in similar locations in all known yeast intervening sequences $(57,66)$. The $5^{\prime}$ exon of $C R Y I$ consists of a short untranslated leader that is 21 to 38 nucleotides long plus $21 / 3$ codons, whereas the $3^{\prime}$ exon contains the remaining $1342 / 3$ codons and a $3^{\prime}$ untranslated sequence that is 123 or 126 nucleotides long.

The fact that most (but not all) yeast ribosomal protein gene transcripts, including $C R Y 1$, contain a single intron near their $5^{\prime}$ ends suggests the possibility that this structural feature is utilized to coordinate the balanced synthesis of yeast ribosomal proteins. Since the CRYI cDNA clone precisely lacking this intron is expressed in cryl yeast cells, 

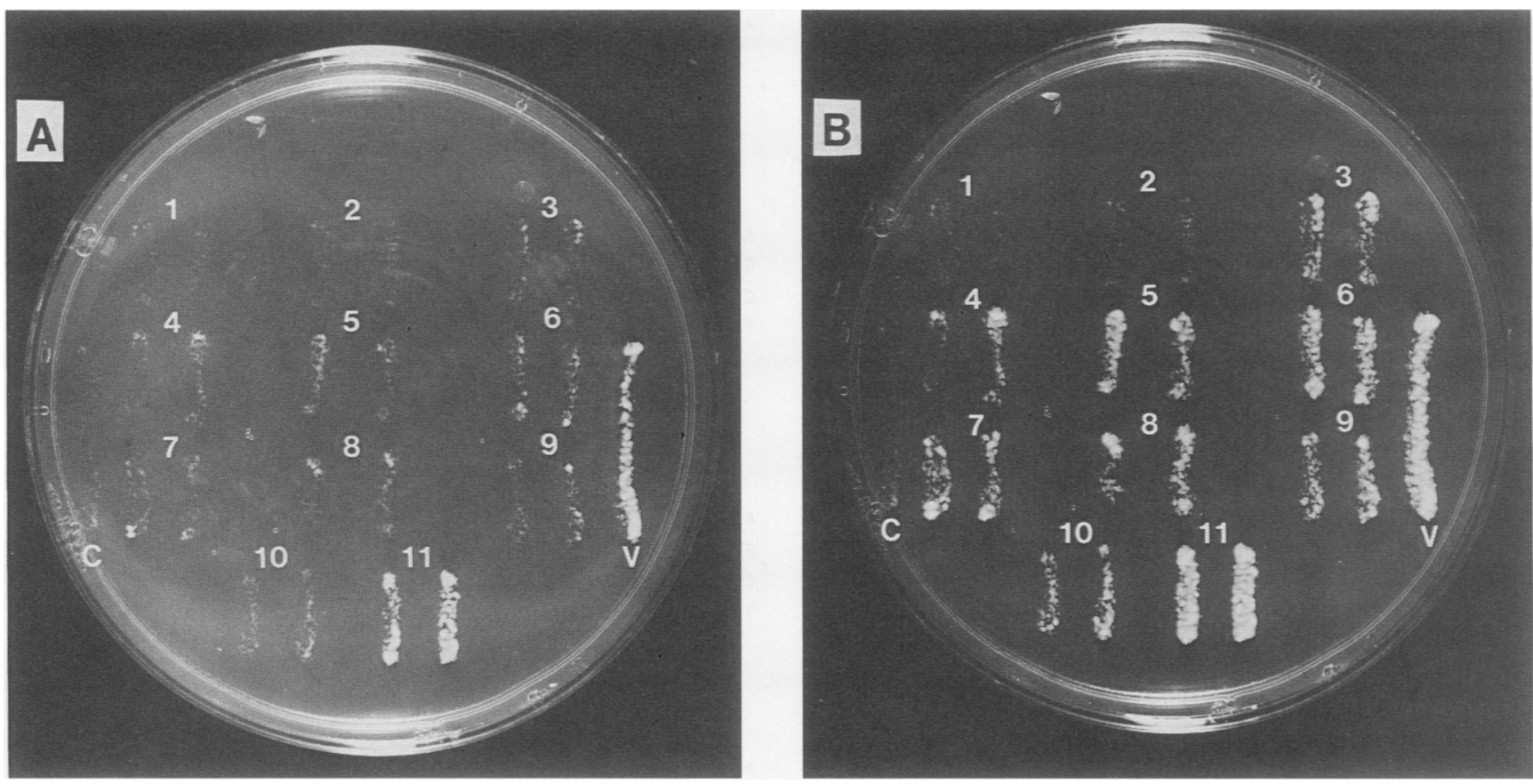

FIG. 7. Cryptopleurine resistance phenotypes of cryl strain JL8 transformed with the YCp50 CRY1 $\Delta 5^{\prime}$ deletion series plasmids. Two independently isolated transformants are shown for each plasmid. The transformed strains were grown on complete dropout medium lacking uracil and replica plated onto plates containing complete medium lacking uracil but containing $10 \mu \mathrm{M}$ cryptopleurine. (A) Growth observed after 2 days at $30^{\circ} \mathrm{C}$. (B) Same plate after 3 days of growth at $30^{\circ} \mathrm{C}$. All strains showed identical growth after 2 days on complete medium lacking uracil and cryptopleurine. The plasmids present in each transformed strain were as follows: C, YCp50 CRYl (2.2-kb HindIII fragment containing $C R Y I$; positive control); V, YCp50 vector (negative control); $1, \Delta-273 ; 2, \Delta-265 ; 3, \Delta-257 ; 4, \Delta-243 ; 5, \Delta-200 ; 6, \Delta-158 ; 7, \Delta-152$; $8, \Delta-143 ; 9, \Delta-123 ; 10, \Delta-114 ; 11, \Delta-46$.

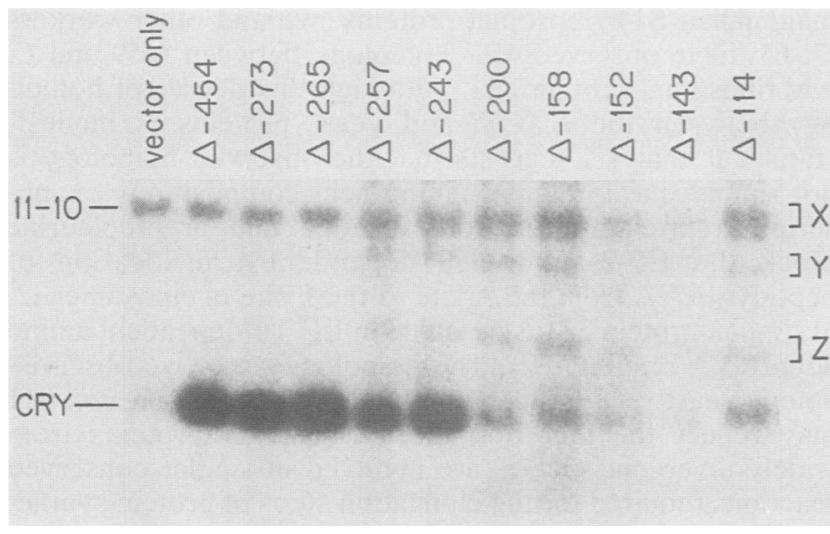

FIG. 8. CRY1 mRNA levels in yeast strain JL8 transformed with the YEp13 CRYI $\triangle 5^{\prime}$ deletion plasmids. Total RNAs were prepared from strains growing on complete dropout medium lacking leucine, subjected to gel electrophoresis, transferred to nitrocellulose, and hybridized with the ${ }^{32} \mathrm{P}$-labeled $C R Y I$ DNA homologous to rp59 mRNA and with plasmid 11-10 homologous to a single abundant yeast transcript. The regions of this nitrocellulose filter corresponding to the $C R Y l$ transcript and the $11-10$ transcript were cut out, and the amount of radioactivity was determined by scintillation counting. These results were entirely in agreement with the RNA levels measured by densitometry (see Fig. 6). X, Y, and Z designate aberrant transcripts only seen when $C R Y 1$ promoter elements were deleted. the $C R Y I$ intron is not necessary for $C R Y 1$ expression. However, the intron may play a role in the modulation of $C R Y 1$ expression. The regulation of expression of the yeast ribosomal protein genes that do not contain introns (e.g., $R P 39 A$ and $R P 39 B$ ) is seemingly identical to that of the intron-containing ribosomal protein genes during heat shock, sporulation, or the stringent response or after a carbon source shift (11, 29, 33; M. Rotenberg and J. Woolford, unpublished data). However, recent data indicate that expression of several ribosomal protein genes during steadystate growth of yeast cells may be regulated in part at the level of mRNA processing (71). Further experiments will be necessary to elucidate the role, if any, of the short 5' exons or the introns or both in the regulation of ribosomal protein gene expression.

Yeast ribosomal protein rp59 is a highly conserved ribosomal protein. The amino acid sequence of $\operatorname{rp} 59$ that we inferred from the DNA sequence of $C R Y I$ displays a striking level of homology $(88 \%)$ to the sequences of both Chinese hamster cell and human S14 ribosomal proteins and a significant level of homology $(45 \%)$ to $E$. coli ribosomal protein S11 (Fig. 5). To our knowledge, this is the strongest sequence homology that has been identified between a yeast ribosomal protein and a mammalian ribosomal protein. Less striking levels of homology have been observed between at least nine other yeast ribosomal proteins and mammalian ribosomal proteins $(7,8,25,37,39,40,50-52)$. DNA sequences homologous to $C R Y I$ have been detected by hybridization to genomic DNA from a number of other organisms, notably Drosophila virilis, Zea mays and Drosophila melanogaster (7; Larkin, unpublished data).

There are mutant alleles of hamster ribosomal protein S14 
gene $E m t B$ that confer resistance in vivo to the translationa elongation inhibitor emetine, as well as cryptopleurine (42). It has been shown that there is a single high-affinity binding site for cryptopleurine that is present on $40 \mathrm{~S}$ ribosomal subunits isolated from wild-type CRYI yeast cells and that ribosomal subunits isolated from cryl yeast cells bind cryptopleurine with lower affinity (10). Although emetine does not enter yeast cells, ribosomes isolated from $\mathrm{Cry}^{\mathrm{r}}$ yeast cells, but not $\mathrm{Cry}^{\mathrm{s}}$ yeast cells, are resistant to emetine in vitro (59). Emetine resistance in Chinese hamster ovary cells results from mutations that alter either Arg codon 149 or Arg codons 149 and 150 of the S14 gene (55). Although the exact locations of cryl mutations have not yet been determined, we note that there are two consecutive Arg codons present near the $3^{\prime}$ end of $C R Y 1$ in a location identical to the location of Arg 149 and 150 codons of $E m t B$ (Fig. 5). Taken together, these data suggest that the S14 proteins of humans and hamsters and the rp59 protein in yeasts contain a conserved site near their carboxyl termini that is necessary for the binding of emetine and cryptopleurine.

In addition to the homology between yeast rp59 and

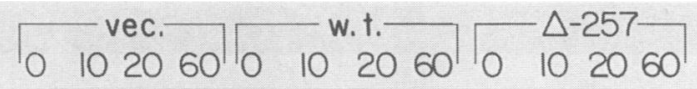

$11-10-$
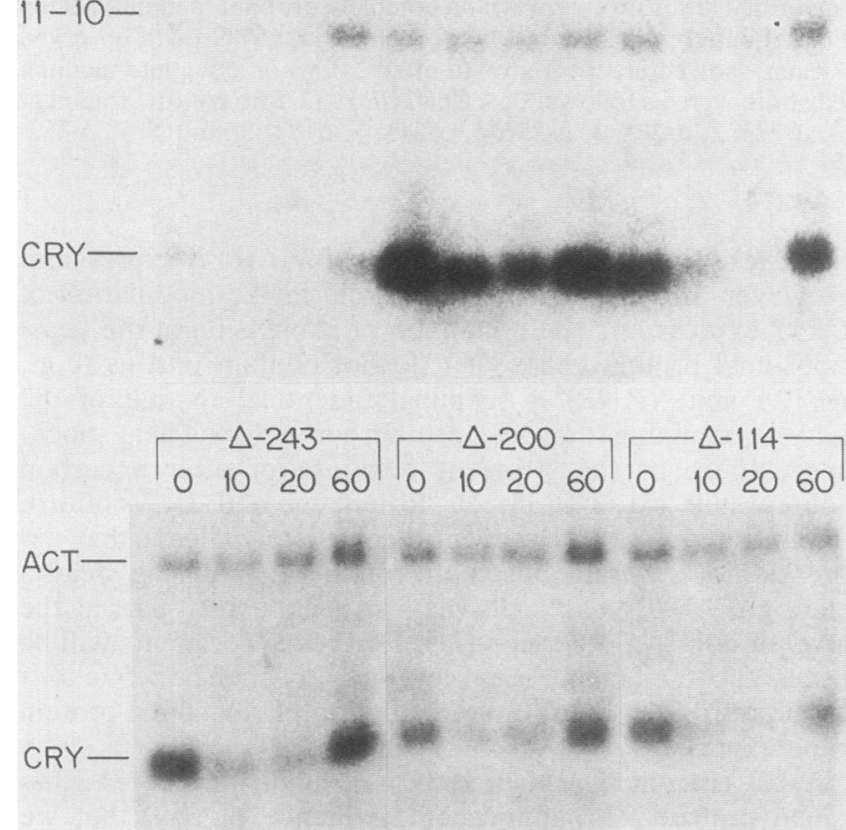

FIG. 9. Transient decrease of transcription of $C R Y I$ during heat shock does not require the HOMOL1 or RPG sequences $5^{\prime}$ to nucleotide -243 upstream of $C R Y 1$. Total RNA was prepared from strain JL8 transformed with YEp13 (vec), YEp 13 containing the wild-type $C R Y 1$ gene (w.t.), and various YEp $13 C R Y 1 \Delta$ plasmids before (0) and 10,20 , or 60 min following a temperature shift from growth in complete dropout medium lacking leucine at $23^{\circ} \mathrm{C}$ to growth at $36^{\circ} \mathrm{C}$, as described in Materials and Methods. The RNA samples were subjected to electrophoresis in denaturing formaldehyde agarose gels, transferred to nitrocellulose, and hybridized with ${ }^{32}$ P-labeled $C R Y 1$ DNA and either ACTI DNA or 11-10 plasmid DNA. The positions of the $C R Y 1, A C T 1$, and $11-10$ mRNAs are indicated. The $C R Y 1 \mathrm{mRNA}$ in the vector transformant represents the mRNA transcribed from the chromosomal $C R Y$ genes and is less than the mRNA seen in all of the CRYI deletion transformants tested.
A. 5' CONSENSUS SEQUENCES OF YEAST TRANSLATIONAL GENES

\begin{tabular}{|c|c|c|c|c|c|c|c|c|c|c|c|c|}
\hline & \multicolumn{12}{|c|}{ HONOL1 } \\
\hline & $A / T$ & $A$ & C & $A$ & $T$ & C & $C / T$ & $G / A$ & $T$ & $A / G$ & C & A \\
\hline A & 11 & 14 & 0 & 15 & 0 & 0 & 1 & 5 & 3 & 12 & 0 & 16 \\
\hline G & 1 & 1 & 0 & 0 & 0 & 0 & 0 & 12 & 0 & 4 & 0 & 0 \\
\hline C & 0 & 1 & 17 & 2 & 1 & 17 & 11 & 0 & 0 & 1 & 16 & 1 \\
\hline$T$ & 5 & 1 & 0 & 0 & 16 & 0 & 5 & 0 & 14 & 0 & 1 & 0 \\
\hline
\end{tabular}

B.

OVERLAP OF THE CONSENSUS SEQUENCES

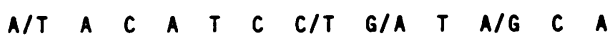

$\begin{array}{llllllllllll}A & C & C & C & A / G & T & A & C & A & T & T / C & T / A\end{array}$

FIG. 10. Compilation of the HOMOL1 and RPG consensus sequences comprising upstream promoter elements of yeast translational genes. (A) Frequency of occurrence of each nucleotide within each position of the dodeca nucleotides HOMOL1 and RPG. The data were compiled from 20 yeast ribosomal protein genes for which sequences are known and the yeast TEFI and TEF2 genes encoding translational elongation factor EF1- $\alpha$ (58). (B) Similarity of the last nine nucleotides of the consensus sequence for HOMOL1 to the first nine nucleotides of the consensus sequence for RPG.

mammalian S14 ribosomal proteins, we and other workers $(7,65)$ have observed $45 \%$ homology between rp59 and $E$. coli ribosomal protein S11. Although this degree of homology between the $E$. coli and yeast proteins is modest, statistical analysis suggests that the observed homology is not simply due to similar amino acid compositions (manuscript in preparation). Both emetine and cryptopleurine block the EF-2- and GTP-dependent translocation of peptidyl-tRNA from the A site to the P site of ribosomes (2, 6). $E$. coli protein $\mathrm{S} 11$ is involved in EF-Tu-dependent amino acyl-tRNA binding (27). The homologies that we observed among yeast rp59, human and hamster S14, and $E$. coli $\mathrm{S} 11$ may reflect the fact that these ribosomal proteins from widely divergent species are involved in similar conserved reactions required for the elongation steps of protein synthesis.

Promoter sequence common to yeast genes encoding components of the translational apparatus. A comparison of the DNA sequences of ribosomal protein genes identified a number of short nucleotide sequences upstream of most of these genes $(38,66)$. To determine whether any of these sequences are involved in the coordinate expression of these genes, it is necessary to isolate mutations in these upstream sequences and assay the expression of these mutant genes in vivo. Our deletion mutations identified the region containing three upstream consensus sequences (HOMOL1, RPG, and the thymine-rich region) as the $C R Y I$ upstream promoter 
element. Through a combination of mutagenesis and promoter substitution analysis we showed previously that the same three sequences comprise the upstream promoter of the $R P 39 A$ gene of yeast cells (58). Similar results have also recently been obtained for yeast ribosomal protein gene $L 25$ (74). These results suggest that the more than 150 genes coding for the translational apparatus of yeast cells share a consensus tripartite promoter sequence. Figure 10 shows a compilation of these consensus sequences determined from the sequences of these genes.

The interaction of specific factors with these consensus promoter sequences could mediate coordinate transcription of this large family of related genes. Recently, Huet et al. (23) identified a DNA binding activity in yeast extracts that interacts with the RPG or HOMOL1 sequences upstream from $T E F 1, T E F 2$, and $R P 51 A$. Competition experiments with $R P 51 A$ and $T E F$ DNAs demonstrated that HOMOL1 and RPG compete for the same binding factors. Since the two consensus sequences are very similar (the last nine nucleotides of HOMOLl are homologous to the first nine nucleotides of RPG [Fig. 10B]), this result is not surprising. In fact, these two sequences actually overlap in the $C R Y I$ promoter at nucleotides -263 to -249 (Fig. 4). Thus, it seems likely that the two sequences are not functionally distinct.

The third component of the CRYI and RP39A upstream promoters that we have identified, a sequence rich in thymine residues, is commonly found upstream of yeast genes (58) and has been demonstrated to function as an upstream promoter element for the constitutive expression of several yeast genes (64). However, our deletion results with both $R P 39 A$ and $C R Y 1$ indicate that HOMOL1 and RPG, as well as the thymine-rich region, are necessary for expression of these genes. Deletion of only parts of the thymine-rich region of the promoter decreases but does not eliminate expression of $R P 39 A$ (58).

The ribosomal protein genes are constitutively transcribed at moderately high levels during steady-state growth (each transcript is $\sim 0.05$ to $0.1 \%$ of the total yeast mRNA), yet under certain growth conditions the expression of ribosomal protein genes is coordinately increased or decreased. One example is the transient decrease in transcription of ribosomal protein genes upon heat shock (31). Both in vitro translation experiments (70) and RNA blotting (31) show that heat shock results in a transient decrease in ribosomal protein mRNA levels. For at least five ribosomal protein genes, this transient reduction in synthesis is due to a dramatic decline in the rate of transcription (31). We have found that the amount of CRYI mRNA normally declines rapidly during the first $20 \mathrm{~min}$ after yeast cells are shifted from 23 to $36^{\circ} \mathrm{C}$ and then recovers fully by $60 \mathrm{~min}$ (Fig. 9), demonstrating that $C R Y I \mathrm{mRNA}$ levels are subject to this mode of coordinate control. Results from the $5^{\prime}$ deletion series demonstrated that the consensus sequences HOMOL1 and RPG are not necessary for the heat shock response of $C R Y 1$. However, we could not unambiguously determine whether sequences $3^{\prime}$ of RPG, including the thymine-rich sequences, were necessary for the heat shock response. The response of yeast gene expression to heat shock is complex. The ribosomal proteins are a subset of more than 300 proteins whose synthesis is transiently repressed during heat shock, whereas the synthesis of at least 80 proteins is increased $(41,47)$. Further experiments will be necessary to determine precisely which sequences are involved in the response of $C R Y I$ to heat shock and whether the heat shock response seen with this gene represents a coordinate response specific to ribosomal protein genes or is reflective of a more general response to heat shock.

\section{ACKNOWLEDGMENTS}

We are grateful to William Brown and Will McClure of the Department of Biological Sciences, Carnegie Mellon University, for $E$. coli DNA polymerase, the Klenow fragment, and T4 polynucleotide kinase, and to Gary McKnight for the yeast cDNA library. We thank our colleagues Robert Last and Mitch Rotenberg for critical discussions during the course of this work, Kathryn Galligan for her tireless typing, Mitch Rotenberg, Steve Scholnick, Peter Lefebvre, Robert Petersen, and Carolyn Silflow for critical readings of the manuscript, and Allison Levy for technical assistance.

This research was supported by Public Health Service grant GM28301 from the National Institutes of Health, by grant W-80 from the Health Research and Services Foundation, and by a grant from the Samuel and Emma Winters Foundation. J.C.L. was supported in part by a scholarship from the Institute of Food Technology; J.R.T. was supported by American Cancer Society Postdoctoral Fellowship PF2631; and J.W. was supported by Public Health Service Research Career Development Award CA-01000 from the National Cancer Institute.

\section{LITERATURE CITED}

1. Abovich, N., and M. Rosbash. 1984. Two genes for ribosomal protein 51 of Saccharomyces cerevisiae complement and contribute to the ribosomes. Mol. Cell. Biol. 4:1871-1879.

2. Barbacid, M., H. Fresno, and D. Vazquez. 1975. Inhibitors of polypeptide elongation of yeast polysomes. J. Antibiot. 28: 453-462.

3. Bingham, P. M., R. Levis, and G. M. Rubin. 1981. Cloning of DNA sequences from the white locus of $D$. melanogaster by a novel and general method. Cell 25:693-704.

4. Bollen, G., L. Cohen, W. Mager, W. Klaasen, and R. J. Planta. 1981. Isolation of cloned ribosomal protein genes from the yeast Saccharomyces carlsbergenesis. Gene 14:279-287.

5. Bollen, G., C. M. T. Molenaar, L. H. Cohen, M. M. C. van Raamsdonk-Duin, W. H. Mager, and R. J. Planta. 1982. Ribosomal protein genes of yeast contain intervening sequences Gene 18:29-38.

6. Bucher, K., and L. Skogerson. 1976. Cryptopleurine-an inhibitor of translocation. Biochemistry 15:4755-4759.

7. Chen, I.-T., A. Dixit, D. Rhoads, and D. Roufa. 1986. Homologous ribosomal proteins in bacteria, yeast, and humans. Proc. Natl. Acad. Sci. USA 83:6907-6911.

8. Davies, M., A. Henney, W. H. J. Ward, and R. Craig. 1986. Characterization of an mRNA encoding a human ribosomal protein homologous to the yeast L44 ribosomal protein. Gene 45:183-191.

9. Davis, R. W., D. Botstein, and J. R. Roth. 1980. Advanced bacterial genetics. Cold Spring Harbor Laboratory Press, Cold Spring Harbor, N.Y.

10. Dolz, H., D. Vazquez, and A. Jimenez. 1982. Quantitation of the specific interaction of $\left[14 \mathrm{a}-{ }^{3} \mathrm{H}\right]$ cryptopleurine with $80 \mathrm{~S}$ and $40 \mathrm{~S}$ ribosomal species from the yeast Saccharomyces cerevisiae. Biochemistry 21:3181-3187.

11. Donovan, D. M., and N. J. Pearson. 1986. Transcriptional regulation of ribosomal proteins during a nutritional upshift in Saccharomyces cerevisiae. Mol. Cell. Biol. 6:2429-2435.

12. Fried, H. M., H. G. Nam, S. Loechel, and J. Teem. 1985. Characterization of yeast strains with conditionally expressed variants of ribosomal protein genes $t \mathrm{cml}$ and $c y h 2$. Mol. Cell. Biol. 5:99-108.

13. Fried, H. M., N. J. Pearson, C. H. Kim, and J. R. Warner. 1981. The genes for fifteen ribosomal proteins of Saccharomyces cerevisiae. J. Biol. Chem. 251:10176-10183.

14. Fried, H. M., and J. R. Warner. 1981. Cloning of yeast gene for trichodermin resistance and ribosomal protein L3. Proc. Natl. Acad. Sci. USA 78:238-242.

15. Fried, H. M., and J. R. Warner. 1982. Molecular cloning and analysis of yeast gene for cycloheximide resistance and ribosomal protein L29. Nucleic Acids Res. 10:3133-3148. 
16. Fried, H. M., and J. R. Warner. 1984. Organization and expression of eukaryotic ribosomal protein genes, p. 169-192. In G. Stein and J. Stein (ed.), Recombinant DNA and cell proliferation. Academic Press, Inc., New York.

17. Gergen, J. P., R. H. Stern, and P. C. Wensink. 1979. Filter replicas and permanent collections of recombinant DNA plasmids. Nucleic Acids Res. 7:2115-2136.

18. Gorenstein, C., and J. R. Warner. 1976. Coordinate regulation of the synthesis of eukaryotic ribosomal proteins. Proc. Natl. Acad. Sci. USA 73:1547-1551.

19. Gorenstein, C., and J. R. Warner. 1977. Synthesis and turnover of ribosomal proteins in the absence of $60 \mathrm{~S}$ subunit assembly in Saccharomyces cerevisiae. Mol. Gen. Genet. 157:327-332.

20. Grant, P., L. Sanchez, and A. Jimenez. 1974. Cryptopleurine resistance: genetic locus for a $40 \mathrm{~S}$ ribosomal component in Saccharomyces cerevisiae. J. Bacteriol. 120:1308-1314.

21. Hereford, L. M., and M. Rosbash. 1977. Number and distribution of polyadenylated RNA sequences in yeast. Cell 10:453462.

22. Himmelfarb, H. J., A. Vassarotti, and J. D. Friesen. 1984. Molecular cloning and biosynthetic regulation of the cryl gene of Saccharomyces cerevisiae. Mol. Gen. Genet. 195:500-506.

23. Huet, J., P. Cottrelle, M. Cool, M.-L. Vignais, D. Thiele, C. Marck, J.-M. Buhler, A. Sentenac, and P. Fromageot. 1985. A general upstream binding factor for genes of the yeast translational apparatus. EMBO J. 4:3539-3547.

24. Ito, H., Y. Fukuda, K. Murata, and A. Kimura. 1983. Transformation of intact yeast cells treated with alkali cations. J. Bacteriol. 153:163-168.

25. Itoh, T., E. Otaka, and K. A. Matsui. 1985. Primary structures of ribosomal protein YS25 from Saccharomyces cerevisiae and its counterparts from Schizosaccharomyces pombe and rat liver. Biochemistry 24:7418-7423.

26. Jones, E. W., and K.-B. Lam. 1973. Mutations affecting levels of tetrahydrofolate interconversion enzymes in Saccharomyces cerevisiae. Mol. Gen. Genet. 123:209-218.

27. Kamp, R., and B. Wittmann-Liebold. 1980. Primary structure of protein S11 from Escherichia coli ribosomes. FEBS Lett. 121:117-122.

28. Kaufer, N. R., H. M. Fried, W. F. Schwindinger, M. Jasin, and J. R. Warner. 1983. Cycloheximide resistance in yeast: the gene and its protein. Nucleic Acids Res. 11:3123-3133.

29. Kief, D. R., and J. R. Warner. 1981. Coordinate control of synthesis of ribosomal ribonucleic acid and ribosomal proteins during nutritional shift-up in Saccharomyces cerevisiae. Mol. Cell. Biol. 1:1007-1015.

30. Kim, C. H., and J. R. Warner. 1983. Messenger RNA for ribósomal proteins in yeast. J. Mol. Biol. 165:79-89.

31. Kim, C. H., and J. R. Warner. 1983. Mild temperature shock alters the transcription of a discrete class of Saccharomyces cerevisiae genes. Mol. Cell. Biol. 3:457-465.

32. Kirby, K. S. 1965 . Isolation and characterization of ribosomal RNA. Biochem. J. 96:266-269.

33. Kraig, E., J. E. Haber, and M. Rosbash. 1982. Sporulation and rna2 lower ribosomal protein mRNA levels by different mechanisms in Saccharomyces cerevisiae. Mol. Cell. Biol. 2:11991204.

34. Krainer, A. R., T. Maniatis, B. Ruskin, and M. R. Green. 1984 Normal and mutant human $\beta$-globin pre-mRNAs are faithfully and efficiently spliced in vitro. Cell 36:993-1005.

35. Larkin, J. C., and J. L. Woolford, Jr. 1983. Molecular cloning and analysis of the $C R Y 1$ gene: a yeast ribosomal protein gene. Nucleic Acids Res. 11:403-420.

36. Last, R. L., J. B. Stavenhagen, and J. L. Woolford, Jr. 1984 Isolation and characterization of the RNA2, RNA3, and RNA11 genes of Saccharomyces cerevisiae. Mol. Cell. Biol. 4:23962405 .

37. Leer, R. J., M. M. C. van Raamsdonk-Duin, P. Kraakman, W. H. Mager, and R. J. Planta. 1985. The genes for yeas ribosomal proteins S24 and L46 are adjacent and divergently transcribed. Nucleic Acids Res. 13:701-709.

38. Leer, R. J., M. M. C. van Raamsdonk-Duin, W. H. Mager, and R. J. Planta. 1985. Conserved sequences upstream of yeast ribosomal protein genes. Curr. Genet. 9:273-277.

39. Leer, R. J., M. M. C. van Raamsdonk-Duin, C. M. T. Molenaar, L. H. Cohen, W. H. Mager, and R. J. Planta. 1982. The structure of the gene coding for the phosphorylated ribosomal protein $\mathrm{S} 10$ in yeast. Nucleic Acids Res. 10:5869-5878.

40. Lin, A., J. McNally, and I. G. Wool. 1983. The primary structure of rat liver ribosomal protein L37: homology with yeast and bacterial ribosomal proteins. J. Biol. Chem. 258:10664-10671.

41. Lindquist, S. 1981. Regulation of protein synthesis during heat shock. Nature (London) 293:311-314.

42. Madjar, J.-J., M. Frahm, S. McGill, and D. J. Roufa. 1983. Ribosomal protein $\mathrm{S} 14$ is altered by two-step emetine resistance mutations in Chinese hamster cells. Mol. Cell. Biol. 3:190-197.

43. Maniatis, T., E. F. Fritsch, and J. Sambrook. 1982. Molecular cloning: a laboratory manual. Cold Spring Harbor Laboratory Press, Cold Spring Harbor, N.Y.

44. Maxam, A. B., and W. Gilbert. 1977. A new method for sequencing DNA. Proc. Natl. Acad. Sci. USA 74:560-564.

45. McKnight, G. L., and B. L. McConaughy. 1983. Selection of functional cDNAs by complementation in yeast. Proc. Natl. Acad. Sci. USA 80:4412-4416.

46. McNeil, J. B., and M. Smith. 1986. Transcription initiation of the Saccharomyces cerevisiae Iso-1-cytochrome c gene. Multiple, independent TATA sequences. J. Mol. Biol. 187:363-378.

47. Miller, M. J., N.-H. Xuong, and E. P. Geiduschek. 1982. Quantitative analysis of the heat shock response of Saccharomyces cerevisiae J. Bacteriol. 151:311-327.

48. Mitra, G., and J. R. Warner. 1984. A yeast ribosomal protein gene whose intron is in the $5^{\prime}$ leader. J. Biol. Chem. 259:9218-9224.

49. Mortimer, R. K., and D. C. Hawthorne. 1969. Yeast genetics, p. 385-460. In A. H. Rose and J. H. Harrison (ed.), The yeasts, vol. 1. Academic Press, Inc., New York.

50. Nakanishi, O., M. Oyanagi, Y. Kuwano, T. Tanaka, T. Nakayama, H. Mitsui, Y. Nabeshima, and K. Ogata. 1985. Molecular cloning and nucleotide sequence of cDNAs specific for rat liver ribosomal proteins S17 and L30. Gene 35:289-296.

51. Otaka, E., K. Higo, and T. Itoh. 1984. Yeast ribosomal proteins. VIII. Isolation of two proteins and sequence characterization of twenty-four proteins from cytoplasmic ribosomes. Mol. Gen. Genet. 195:544-546.

52. Otaka, E., K. Higo, and S. Osawa. 1982. Isolation of seventeen proteins and amino-terminal amino acid sequences of eight proteins from cytoplasmic ribosomes of yeast. Biochemistry 21:4545-4550.

53. Pearson, N. J., H. M. Fried, and J. R. Warner. 1982. Yeast use translational control to compensate for extra copies of a ribosomal protein gene. Cell 29:347-355.

54. Rhoads, D., A. Dixit, and D. Roufa. 1986. Primary structure of human ribosomal protein S14 and the gene that encodes it. Mol. Cell. Biol. 6:2774-2783.

55. Rhoads, D. D., and D. J. Roufa. 1985. Emetine resistance of Chinese hamster cells: structures of wild-type and mutant ribosomal protein S14 mRNAs. Mol. Cell. Biol. 5:1655-1659.

56. Rigby, P. W. J., M. Diekmann, C. Rhodes, and P. Berg. 1977. Labeling deoxyribonucleic acid to high specific activity in vitro by nick translation with DNA polymerase I. J. Mol. Biol. 113:237-251.

57. Rosbash, M., P. K. W. Harris, J. L. Woolford, Jr., and J. L. Teem. 1981. The effect of temperature sensitive RNA mutants on the transcription products from cloned ribosomal protein genes of yeast. Cell 24:679-686.

58. Rotenberg, M. O., and J. L. Woolford, Jr. 1986. Tripartite upstream promoter element essential for expression of Saccharomyces cerevisiae ribosomal protein genes. Mol. Cell. Biol. 6:674-687

59. Sanchez, L., D. Vazquez, and A. Jimenez. 1977. Genetics and biochemistry of cryptopleurine resistance in the yeast Saccharomyces cerevisiae. Mol. Gen. Genet. 156:319-326.

60. Schultz, L. D., and D. J. Friesen. 1983. Nucleotide sequence of the $\mathrm{tcml}$ gene (ribosomal protein L3) of Saccharomyces cerevisiae. J. Bacteriol. 155:8-14.

61. Sherman, F., G. Fink, and C. W. Lawrence. 1979. Methods in 
yeast genetics. Cold Spring Harbor Laboratory Press, Cold Spring Harbor, N.Y.

62. Skogerson, L., C. McLaughlin, and E. Wakatama. 1973. Modification of ribosomes in cryptopleurine-resistant mutants of yeast. J. Bacteriol. 116:818-822.

63. Southern, E. M. 1975. Detection of specific sequences among DNA fragments separated by gel electrophoresis. J. Mol. Biol. 98:503-517.

64. Struhl; K. 1985. Naturally occurring poly(dA-dT) sequences are upstream promoter elements for constitutive transcription in yeast. Proc. Natl. Acad. Sci. USA 82:8419-8423.

65. Tanaka, T., K. Ishikawa, and K. Ogata. 1986. On the sequence homology of the ribosomal proteins, Escherichia coli S11, yeast rp59, and Chinese hamster S14. FEBS Lett. 202:295-297.

66. Teem, J. L., N. Abovich, N. F. Kaufer, W. F. Schwindinger, J. R. Warner, A. Levy, J. Woolford, R. J. Leer, M. M. C. van Raamsdonk-Duin, W. H. Mager, R. J. Planta, L. Schultz, J. D. Friesen, H. Fried, and M. Rosbash. 1984. A comparison of yeast ribosomal protein gene DNA sequences. Nucleic Acids Res. 12:8295-8312.

67. Teem, J. L., and M. Rosbash. 1983. Expression of a $\beta$ galactosidase gene containing the ribosomal protein $5^{\prime}$ intron is sensitive to the rna2 mutation of yeast. Proc. Natl. Acad. Sci. USA 80:4403-4407.
68. Treisman, R., S. H. Orkin, and T. Maniatis. 1983. Specific transcription and RNA splicing defects in five cloned $\beta$ thalassemia genes. Nature (London) 302:591-596.

69. Udem, S. A., and J. R. Warner. 1972. Synthesis and processing of ribosomal RNA in Saccharomyces cerevisiae. J. Mol. Biol. 65:227-242.

70. Warner, J. R., and C. Gorenstein. 1977. The synthesis of eukaryotic ribosomal proteins in vitro. Cell 11:201-212.

71. Warner, J. R., G. Mitra, W. F. Schwindinger, M. Studeny, and H. M. Fried. 1985. Saccharomyces cerevisiae coordinates accumulation of yeast ribosomal proteins by modulating mRNA splicing, translational initiation, and protein turnover. Mol. Cell. Biol. 5:1512-1521.

72. Woolford, J. L., Jr., L. Hereford, and M. Rosbash. 1979. Isolation of cloned DNA sequences containing ribosomal protein genes from Saccharomyces cerevisiae. Cell 18:1247-1259.

73. Woolford, J. L. Jr., and M. Rosbash. 1981. Ribosomal protein genes rp39 (10-78), rp39 (11-40), rp51, and rp52 are not contiguous to other ribosomal protein genes in the Saccharomyces cerevisiae genome. Nucleic Acids Res. 9:5021-5036.

74. Woudt, L. P., A. B. Smit, W. H. Mager, and R. J. Planta. 1986. Conserved sequence elements upstream of the gene encoding yeast ribosomal protein $\mathbf{L 2 5}$ are involved in transcription activation. EMBO J. 5:1037-1040. 